$14^{\text {th }}$ Conf. Agric. Develop. Res., Fac. of Agric.,

Ain Shams Univ., March, 2019., Cairo, Egypt

Special Issue, 27(1), 479 - 489, 2019

Website: http://strategy-plan.asu.edu.eg/AUJASCI/

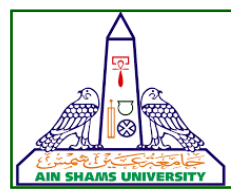

\title{
OPTIMIZATION THE ALGINATE PRODUCTION CONDITIONS IN SWEET WHEY MEDIUM BY AZOTOBACTER CHROCOCCUM
}

Walaa $^{{ }^{\star}}$. S. Hendawy, El Kanani Y.M. ${ }^{2}$, El Batawy O.I. ${ }^{2}$ and EI mongy, T. M. ${ }^{1}$

1. Microbiology Dept., National Center for Radiation Research \& Technol., Atomic Energy Authority, P.O. Box 29, Nasr City, Cairo, Egypt

2. Food Sci. Dept., Fac. of Agric., Ain Shams Univ., P.O. Box 68 Hadyek Shoubra11241, Cairo, Egypt

*Corresponding author: walaahendawy78@gmail.com

Received 25 October , 2018, $\quad$ Accepted 11 November, 2018

\section{ABSTRACT}

Sweet whey was used as medium for microbial alginate production by Azotobacter chrococcum $\mathrm{NCBI} \mathrm{MH} 249629$. To optimize alginate production and achieve high yield of alginate, sweet whey medium was prepared using different lactose concentrations $(20,25,30,35,40,45,50 \mathrm{~g} / \mathrm{L})$, added organic and inorganic nitrogen sources (yeast extract, Malt extract, ammonium sulphate and ammonium nitrate), kept at different temperatures (25, $\left.30,32,35 \& 37^{\circ} \mathrm{C}\right)$, different $\mathrm{pH}$ values $(4,5,6,7$, $8,9)$, different agitation speed $(100,120,150,170$ \& $200 \mathrm{rpm})$, different inoculum size $(1,2,3,4,5,6,7,8,9,10 \%)$ and cultivated for different fermentation time $(0,12,24,36,48,60,72,84,96$, $108 \& 120 \mathrm{~h})$. After fermentation time, produced microbial alginate was measured. The results showed that sweet whey could be used as a fermentation medium by Azotobacter chrococcum to produce microbial alginate. The highest yield of alginate $(12.56 \%)$ as well as productivity of alginate $(0.08 \mathrm{~g} / \mathrm{L} / \mathrm{h})$ was obtained by fermentation of Azotobacter chrococcum in sweet whey medium optimized to $45 \mathrm{~g} / \mathrm{L}$ lactose concentration as a carbon source and by providing the following conditions which yeast extract $1.5 \mathrm{~g} / \mathrm{L}$ and ammonium nitrate $0.1 \mathrm{~g} / \mathrm{L}$ as a nitrogen source and growth promoter, $\mathrm{Na}_{2} \mathrm{HPO}_{4} 1 \mathrm{~g} / \mathrm{L}$ as mineral salts, Initial $\mathrm{pH}$ at 7 , size of standard inoculums was $9 \%$ of fermentation medium and the incubation period was 72 hrs.

Key words: Alginate production, Sweet whey, Azotobacter ssp., Fermentation conditions.

\section{INTRODUCTION}

Alginates are a polysaccharides composed of variable ratios of $\beta$-D-mannuronate $(M)$ and its $C-5$ epimer $\alpha$-Lguluronate $(G)$ linked by $1-4$ glycosidic bonds. Alginates were first isolated from brown seaweeds in the $1880 \mathrm{~s}$, and its commercial production begun in the early 20th century. Alginate can be produced by various genera of brown seaweed and two genera of bacteria, Pseudomonas and Azotobacter spps. The ratio of $\mathrm{M}$ and $\mathrm{G}$ residues and thus the material properties vary depending on the source of the alginate. Its unique physical properties enable it to be used as a stabilizer, viscosifier and gelling agent in the food, beverage, paper, printing and pharmaceutical industries (Draget et al 2005 and Donati \& Paoletti, 2009). The desirable material properties as well as its apparent biocompatibility has led to it being used increasingly in the medical, pharmaceutical and biotechnology industries for applications such as wound dressings (Thomas, 2000); the encapsulation or controlled release of drugs, enzymes or cells; or as matrices for tissue engineering (Andersen et al 2012 and Lee \& Mooney, 2012).

Azotobacter are non-symbiotic diazotrophic bacteria generally found in neutral or slightly alkaline soils, including aerially transported dust and mostly abundant in plant rhizosphere and phyllosphere region. Members of the genus Azotobacter, are free living, gram negative, aerobic and heterotrophic in nature (Garg et al 2001). Azotobacter spp. is well known to produce large quantities of extracellular polysaccharides (EPS), commonly apparent as large mucoid colonies during isolation 
from soil habitat (Vargas-Garcia et al 2002). EPS provide protection to cells against desiccation and predation by protozoans or phage attack (Looijesteijn et al 2001). This polysaccharide also protects the penetration of toxic metal ions inside the cell (Aleem et al 2003) and nitrogenase against high oxygen concentration environment (Sabra et al 2000 and Soto-Urzúa \& Baca, 2001).

In the case of the dairy industry, one such 'waste' which is produced in enormous quantities is the whey resulting from cheese and casein manufacture. Whey is the serum part of milk remaining after separation of the curds during casein or cheese making (Zadow, 1986). It is rich in nutrients and contains at least half the solids found in whole milk (Horton, 1993). The other perspective, whey has a very strong polluting capacity, with a Biological Oxygen Demand (BOD) of 40,000 to 45,000 mg/L (Hacking, 2006 and Kemp \& Quickenden, 1989). On a world wide scale, only $50 \%$ $(\mathrm{v} / \mathrm{v})$ of total whey produced is utilized, and the remainder is disposed of disposed whey is either discharged into the sewage or ocean outfall or is sprayed on pastures (Zadow, 1987 \& 1992). In recent years, value added products from whey have attracted much interest. One such area is the production of microbial biopolymer (Schwartz and Bodie, 1985, Fu and Tseng, 1990, Flatt, et al 1992 and Konicek et al 1993).

Therefore, the aim of this study was to optimize alginate production conditions by identified Azotobacter chrococcum NCBI MH249629 in shake flasks using sweet whey medium.

\section{MATERIALS AND METHODS}

\section{Materials}

Sweet whey $(0.27 \%$ protein, $4.9 \%$ lactose, $0.5 \%$ ash and $5.8 \%$ total solids) from Gouda cheese manufacturing was obtained from Dina for Agricultural Investments Co., Alexandria Desert Road, It was characterized for its composition using the Milko Scan method (Microbalance 4503 MP6).

Azotobacter chrococcum was isolated from rhizospheric soil samples and identified according to Bergye's Manual of systematic bacteriology. (George et al 2001) Screening and selection of the strain have been made on the basis of their exopolysaccharides production (EPS) ability in nitrogen-free glucose Burk's medium (glucose, 20g; $\mathrm{K}_{2} \mathrm{HPO}_{4}, 0.2 \mathrm{~g} ; \mathrm{FeSO}_{4}, 0.1 \mathrm{~g} ; \mathrm{MgSO}_{4}, 0.2 \mathrm{~g}$; $\mathrm{NaCl}, 0.2 \mathrm{~g} ; \mathrm{CaCO}_{3}, 5 \mathrm{~g} ; \mathrm{Na}_{2} \mathrm{MoO}_{4} 0.01 \mathrm{~g}$; water, $1000 \mathrm{ml}$ ). The $\mathrm{pH}$ was adjusted to 7 with a concentrated $\mathrm{NaOH}$ solution. To avoid precipitation during autoclaving, the solutions of $\mathrm{FeSO}_{4}$ á $7 \mathrm{H}_{2} \mathrm{O}$ and $\mathrm{Na}_{2} \mathrm{MoO}_{4} .2 \mathrm{H} 2 \mathrm{O}$ were separated from the other medium components during sterilization $\left(121^{\circ} \mathrm{C}\right.$, $35 \mathrm{~min}$ ). (Vela and Rosenthal, 1972). The selected strain was identified by $16 \mathrm{~S}$ rDNA sequencing and designated as SSB81.

For 16S rDNA sequencing, total genomic DNA was extracted from the isolate following the method (Agrawal et al 2015). Amplification of $16 \mathrm{~S}$ rDNA gene by PCR using universal primer, Forward (5'-AGAGTTTGATCCTGGCTCAG-3'), Reverse (5'- AAGGAGGTGATCCAGCCGCA-3'). All data reported in this study are from triplicate measurement.

\section{Culture media and conditions}

Sweet whey was autoclaved at $121^{\circ} \mathrm{C}$ for $5 \mathrm{~min}$ to precipitate the whey protein; the precipitate was removed by filtration through Whatman paper No.1 (Ricciardi and Clementi, 2002). The whey production medium for the highest alginate producing strain (Azotobacter chrococcum NCBI MH249629) contained: $0.1 \%(\mathrm{w} / \mathrm{v})$ yeast extract, $0.05 \%(\mathrm{w} / \mathrm{v})$ malt extract, $0.05 \%$ (w/v) $\mathrm{Na}_{2} \mathrm{HPO}_{4}, 0.01 \%$ (w/v) $\mathrm{NH}_{4} \mathrm{NO}_{3}, 0.01 \%(\mathrm{w} / \mathrm{v}) \mathrm{MgSO}_{4}$. Culture was performed in $250 \mathrm{ml}$ Erlenmeyer flasks with a working volume of $50 \mathrm{ml}$ then Each flask was inoculated with different inoculum size $(1,2,3,4,5,6,7,8,9$, $10 \%)$ which prepared with different lactose concentration $(20,25,30,35,40,45,50 \mathrm{~g} / \mathrm{L})$, added organic and inorganic nitrogen sources (yeast extract, Malt extract, ammonium sulphate and ammonium nitrate $1 \mathrm{~g} / \mathrm{L})$, kept at different temperatures $\left(25,30,32,35 \& 37^{\circ} \mathrm{C}\right)$ and different agitation speed $(100,120,150,170 \& 200 \mathrm{rpm} / \mathrm{h})$, cultivated for different fermentation time $(0,12,24,36,48$, $60,72,84,96,108 \& 120 \mathrm{~h})$, different $\mathrm{pH}(4,5,6,7$, $8,9)$ to optimize alginate production and achieve high yield of alginate (Butt et al 2011).

\section{Growth curve}

Samples were taken every $24 \mathrm{~h}$ to measure optical density (OD 400nm) by spectrophotometer assay using (model V-200-RS, visible light, LW scientific), according to the method described by Painter and Morr (1963). 


\section{Growth and biological activity parameter}

The specific growth rate $(\mu)$ and doubling time $\left(t_{d}\right)_{\text {_n }}$ were calculated from the exponential phase according to Painter and Morr (1963) using the following equation: -

$$
\begin{aligned}
& \mu=\left(\ln x-\ln x_{o}\right)\left(t-t_{o}\right)^{-1} \\
& \mu=\ln 2 t_{d}^{-1}
\end{aligned}
$$

where

$\mu=$ Specific growth rate $\left(\mathrm{h}^{-1}\right)$

$x_{0}=$ Amount of growth at $t_{0}$ time

$\mathrm{x}=$ Amount of growth after $\mathrm{t}$ time

$t_{d}=$ Doubling time $(h)$

$t_{0}=$ Time in hours at the beginning of log phase

$t=$ Time in hours at the end of log phase

Number of generations was calculated using the following equation according to Stanier et al (1970):

$$
\mathbf{N}=\mathbf{t} / \mathbf{t}_{\mathbf{d}}
$$

Where

$\mathrm{N}=$ Number of generation

$\mathrm{t}=$ The period of exponential phase

$t_{d}=$ Doubling time $(h)$

\section{Measurement of produced microbial alginate}

10- $\mathrm{ml}$ of sample was centrifuged at $6000 \mathrm{rpm}$ at $4^{\circ} \mathrm{C}$ for $301 \mathrm{~min}$. The precipitate (biomass) was suspended in $10 \mathrm{Mm}$ EDTA with $\mathrm{NaCl}$ for 2 min to solubilize the cell associated alginate then centrifuged at $8000 \mathrm{rpm}$ at $4^{\circ} \mathrm{C} / 30 \mathrm{~min}$ and washed twice with distilled water, centrifuged and dried at $90^{\circ} \mathrm{C}$ till constant weight for $18 \mathrm{~h}$. Alginate polysaccharides in cell-free supernatant was recovered by precipitation with three volumes of propanol (95\% $\mathrm{v} / \mathrm{v})$, after centrifugation at $8000 \mathrm{rpm}$ at $4^{\circ} \mathrm{O} / 30 \mathrm{~min}$ and dried at $70^{\circ} \mathrm{C}$ till constant weight (Pena et al 2011).

\section{Statistical analysis}

The final, optimized experiments were run in triplicate and the data plotted are the mean value $\pm S D$, the calculations were performed using IBM SPSS Statistics V.22 software through One-Way ANOVA technique and multiple comparisons were made through Least Significant Difference test (Steel et al 1997).

\section{RESULTS AND DISCUSSION}

Effect of lactose concentration in sweet whey media on the production of microbial alginate

Carbon source had a dual effect as the building block and the energy requirement for the organism. Suitable and readily absorbable sugars can be the best choice for bacterial growth to gain good production (Alibutt et al 2011). In this study the effect of different lactose concentrations in sweet whey medium on the production of microbial alginate by Azotobacter chrococcum NCBI MH249629 is shown in Table (1).

Table 1. Effect of different concentrations of lactose (milk sugar) in sweet whey medium on alginate production by Azotobacter chrococcum.

\begin{tabular}{|c|c|c|c|c|c|c|}
\hline $\begin{array}{c}\text { Why dilution } \\
\text { (why/water) } \\
(\mathbf{V} / \mathbf{V})\end{array}$ & $\begin{array}{c}\text { Why Lactose conc. } \\
\text { (g/L) }\end{array}$ & $\begin{array}{c}\text { CDW } \\
\mathbf{( g / L )}\end{array}$ & $\begin{array}{c}\text { Alginate conc. } \\
(\mathbf{g} / \mathbf{L})\end{array}$ & $\begin{array}{c}\text { Productivity } \\
(\mathbf{g} / \mathbf{L} / \mathbf{h})\end{array}$ & Yield $(\%)$ & Final $\mathbf{p H}$ \\
\hline $4: 6$ & 20 & $0.658 \pm 0.002$ & $0.645 \pm 0.023$ & $0.0054 \pm 0.001$ & $3.23 \pm 0.020$ & 6.91 \\
$1: 1$ & 25 & $0.706 \pm 0.006$ & $0.682 \pm 0.020$ & $0.0057 \pm 0.001$ & $2.73 \pm 0.026$ & 6.85 \\
$6: 4$ & 30 & $0.732 \pm 0.002$ & $0.716 \pm 0.012$ & $0.0059 \pm 0.001$ & $2.39 \pm 0.021$ & 6.63 \\
$7: 3$ & 35 & $0.829 \pm 0.006$ & $0.754 \pm 0.015$ & $0.0063 \pm 0.004$ & $2.15 \pm 0.021$ & 6.50 \\
$8: 2$ & 40 & $0.976 \pm 0.002$ & $0.923 \pm 0.026$ & $0.0077 \pm 0.001$ & $2.31 \pm 0.025$ & 6.39 \\
$9: 1$ & 45 & $0.939 \pm 0.007$ & $0.983 \pm 0.006$ & $0.0082 \pm 0.002$ & $2.18 \pm 0.010$ & 6.20 \\
$1: 0$ & 50 (Control) & $0.794 \pm 0.014$ & $0.763 \pm 0.010$ & $0.0064 \pm 0.003$ & $1.53 \pm 0.032$ & 6.43 \\
\hline
\end{tabular}

*Initial $\mathrm{pH}=7$

${ }^{*}$ The present values are the average of three replicates $\pm S D$.

*Whey medium; After 5 days of incubation period at $30^{\circ} \mathrm{C} ; 170 \mathrm{rpm}$.

${ }^{*}$ CDW: Cell dry weight 
The results indicate that, variation of lactose concentration in sweet whey medium had a significant effect on the production of alginate produced by Azotobacter chrococcum NCBI MH249629. The data illustrate that the highest alginate concentration, productivity $(0.983 \mathrm{~g} / \mathrm{L}, 0.0082 \mathrm{~g} / \mathrm{L} / \mathrm{h})$ respectively at $4.5 \%$ lactose $(\mathrm{v} / \mathrm{v}),(5 \%)$ inoculum size, $30^{\circ} \mathrm{C} / 120 \mathrm{~h}$. While at $4 \%$ lactose gave maximum biomass $(0.976 \mathrm{~g} / \mathrm{L})$ among all treatments. Increasing lactose concentration to $5 \%$ (control treatment) led to a significant decrease in alginate concentration compared with treatment containing $4.5 \%$ lactose. This is may be due to the effect of increasing the concentration of lactose in the medium inhibits the growth of Azotobacter ssp. and decrease the production of alginate (Alibutt et al 2011). This inhibitory effect might be attributed to high osmotic pressure (Prasertan et al 2008). Lactose is the most abundant constituent of whey and it forms at least $78 \%(w / w)$ of the whey's total solids, this indicates that for an organism to efficiently use whey as substrate, it must be able to metabolize the lactose as its carbon source. Such organisms should produce sufficient lactose hydrolyzing enzymes ( $\beta$-galactosidase) to hydrolyze the lactose to its monomers (Belder, 2010 and Kang et al 2010). These findings are in harmony with the previous results obtained by (Emitazi et al 2004) who revealed that Azotobacter chrococcum 1723 was able to produce alginate greater than $5 \mathrm{mg} / \mathrm{L}$ when used lactose as carbon source.

Generally, it could be concluded that $4.5 \%$ lactose $(\mathrm{v} / \mathrm{v})$ was the most favorable concentration as a carbon source for alginate production by Azotobacter chrococcum NCBI MH249629 in sweet whey medium.

\section{Effect of different nitrogen sources in sweet whey media on the production of microbial al- ginate}

As shown in Table (2) it could be stated that using different nitrogen sources either organic or inorganic in sweet whey medium have a significant effect on the values of (CDW) and alginate concentration produced by Azotobacter chrococcum NCBI MH249629. the control treatment (without any additives) was the lowest alginate concentration $(0.719 \mathrm{~g} / \mathrm{L})$ among all treatments, whereas yeast extract gives the highest alginate concentration $(0.984 \mathrm{~g} / \mathrm{L})$. This is means that, fortification the sweet whey medium with $1 \%$ different nitrogen sources (yeast extract, malt extract, peptone, ammonium sulphate, ammonium nitrate) caused significant increase in alginate concentration produced by Azotobacter chrococcum NCBI MH249629.

Table 2. Effect of different nitrogen sources in sweet whey medium on the production of microbial alginate.

\begin{tabular}{|c|c|c|c|c|c|}
\hline $\begin{array}{c}\text { Nitrogen sources } \\
(1 \mathrm{~g} / \mathrm{L})\end{array}$ & $\begin{array}{l}\text { CDW } \\
(g / L)\end{array}$ & $\begin{array}{c}\text { Alginate conc. } \\
(\mathrm{g} / \mathrm{L})\end{array}$ & $\begin{array}{l}\text { Productivity } \\
(\mathrm{g} / \mathrm{L} / \mathrm{h})\end{array}$ & $\begin{array}{l}\text { Yield } \\
(\%)\end{array}$ & Final $\mathrm{pH}$ \\
\hline 0.0 & $0.815 \pm 0.035$ & $0.719 \pm 0.004$ & $0.006 \pm 0.002$ & $1.59 \pm 0.051$ & 7.75 \\
\hline Yeast extract & $1.155 \pm 0.02$ & $0.984 \pm 0.004$ & $0.008 \pm 0.003$ & $2.18 \pm 0.041$ & 7.32 \\
\hline Malt extract & $0.964 \pm 0.038$ & $0.945 \pm 0.002$ & $0.008 \pm 0.003$ & $2.10 \pm 0.032$ & 7.50 \\
\hline Peptone & $0.897 \pm 0.022$ & $0.899 \pm 0.026$ & $0.008 \pm 0.006$ & $1.99 \pm 0.04$ & 7.38 \\
\hline Ammonium sulphate & $0.685 \pm 0.025$ & $0.667 \pm 0.007$ & $0.006 \pm 0.006$ & $1.48 \pm 0.032$ & 7.64 \\
\hline Ammonium nitrate & $0.831 \pm 0.048$ & $0.755 \pm 0.005$ & $0.006 \pm 0.004$ & $1.67 \pm 0.051$ & 7.70 \\
\hline
\end{tabular}

* Legend as Table (1).

From the presented data, it could be stated that, using the inorganic nitrogen sources in sweet whey medium such as (ammonium nitrate) give significant more alginate concentration produced (0.755 $\mathrm{g} / \mathrm{L})$ by Azotobacter chrococcum NCBI $\mathrm{MH} 249629$ than that using ammonium sulphate $(0.667 \mathrm{~g} / \mathrm{L})$. Our results are agreeing with (Anyance 2008) who notice that addition of inorganic nitrogen led to enhance growth of Azotobacter ssp.,
Fig. (1) represent the highest values of cell dry weight, alginate concentration, productivity and yield were attained in sweet whey medium supplemented with $(1.5 \mathrm{~g} / \mathrm{L})$ yeast extract being $(1.155 \mathrm{~g} / \mathrm{L}, 0.984 \mathrm{~g} / \mathrm{L}, \quad 0.008 \mathrm{~g} / \mathrm{L} / \mathrm{h}$ and $2.18 \%)$ respectively. Fig. (2) represent the highest values of cell dry weight, alginate concentration, productivity and yield were attained in sweet whey medium supplemented with $(0.5 \mathrm{~g} / \mathrm{L})$ ammonium nitrate as sole nitrogen source being $(1.323 \mathrm{~g} / \mathrm{L}, 1.260 \mathrm{~g} / \mathrm{L}$, $0.01 \mathrm{~g} / \mathrm{L} / \mathrm{h}, 2.8 \%)$. Addition of $(1.5 \mathrm{~g} / \mathrm{L})$ yeast extract 
and $(0.5 \mathrm{~g} / \mathrm{L})$ ammonium nitrate in sweet whey medium gave higher values of (CDW) and alginate concentration $(\mathrm{g} / \mathrm{L})$ compared with other organic or in-organic nitrogen sources.

Increasing yeast extract concentration in the mixture nitrogen source (organic and inorganic nitrogen sources) of productive medium led to increase the cell dry weight, alginate concentration, productivity and yield to reach the maximum values being (1.155g/L, $1.17 \mathrm{~g} / \mathrm{L}, 0.0097 \mathrm{~g} / \mathrm{L} / \mathrm{h} \& 2.6 \%)$ respectively at $1.5 \mathrm{~g} / \mathrm{L}$ yeast extract after 5 days at $30^{\circ} \mathrm{C} \mathrm{Fig.} \mathrm{(1).} \mathrm{It} \mathrm{might} \mathrm{be} \mathrm{due} \mathrm{to} \mathrm{the} \mathrm{fact} \mathrm{that} \mathrm{or-}$ ganic nitrogen provides better available nitrogen for bacterial growth and alginate production. This data sported by the results recorded by (Alibutt et al 2011). Also, Gayathri et al 2012 notice that increasing yeast extract and ammonium nitrate as organic and inorganic nitrogen sources showed highest production of alginate.

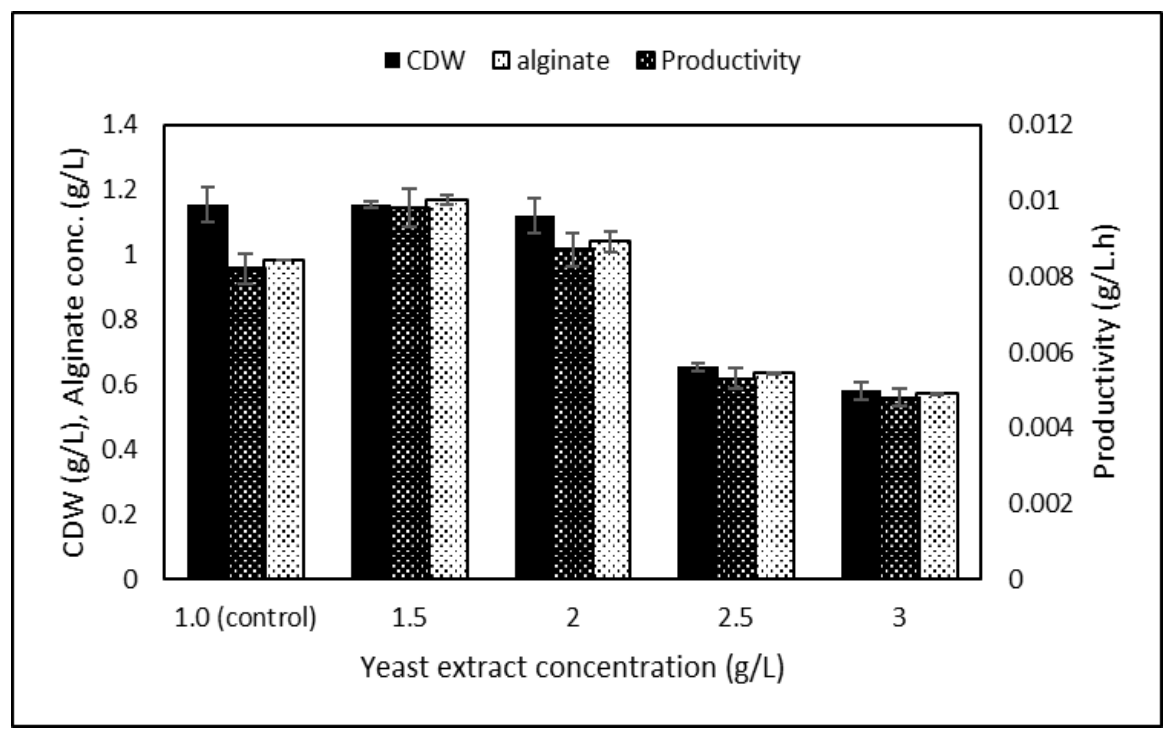

Fig. 1. Effect of different yeast extract concentrations in sweet whey medium on the production of microbial alginate.

* Legend as Table (1).

Effect of different disodium hydrogen phosphate concentrations in sweet whey medium on alginate production by Azotobacter chrococcum

Phosphate might simply act to buffer the medium which will tend to become more acidic as alginate is secreted and use a phosphate rich medium (Brivonese and Sutherland 1989). The data illustrated by Fig. (2) revealed the stimulatory effect of $\mathrm{Na}_{2} \mathrm{HPO}_{4}$ in the sweet whey medium used for produce microbial alginate by Azotobacter chrococcum. The highest cell dry weight, alginate concentration, productivity and yield obtained from sweet whey medium containing $\mathrm{Na}_{2} \mathrm{HPO}_{4}$ at $1 \mathrm{~g} / \mathrm{L}$ $(2.493 \mathrm{~g} / \mathrm{L}, 2.48 \mathrm{~g} / \mathrm{L}, 0.021 \mathrm{~g} / \mathrm{L} / \mathrm{h} \& 5.51 \%)$ respectively. While increasing the concentration of $\mathrm{Na}_{2} \mathrm{HPO}_{4}$ up $1 \%$ led to significant decrease in cell dry weight, alginate concentration, productivity and yield obtained by Azotobacter chrococcum. These results are in line of those obtained by Deavin (1976) and Deavin et al (1977), they stated that the alginate production by a mutant $A$. vinelandii in continuous culture was depended on inorganic phosphate concentration. Also, Sabra et al (2000) observed the drop in alginate yield in medium containing excess of phosphate concentration and for their continuous culture studied a phosphate limitation gave maximum alginate production.

Effect of initial pH of sweet whey medium on alginate production by Azotobacter chrococcum

Hydrogen ion concentration has a significant influence on industrial fermentation due to much its importance in controlling bacterial growth, fermentation rates and product formation. The variation in growth rate related to the $\mathrm{pH}$ presents an optimum value and extreme limits. 


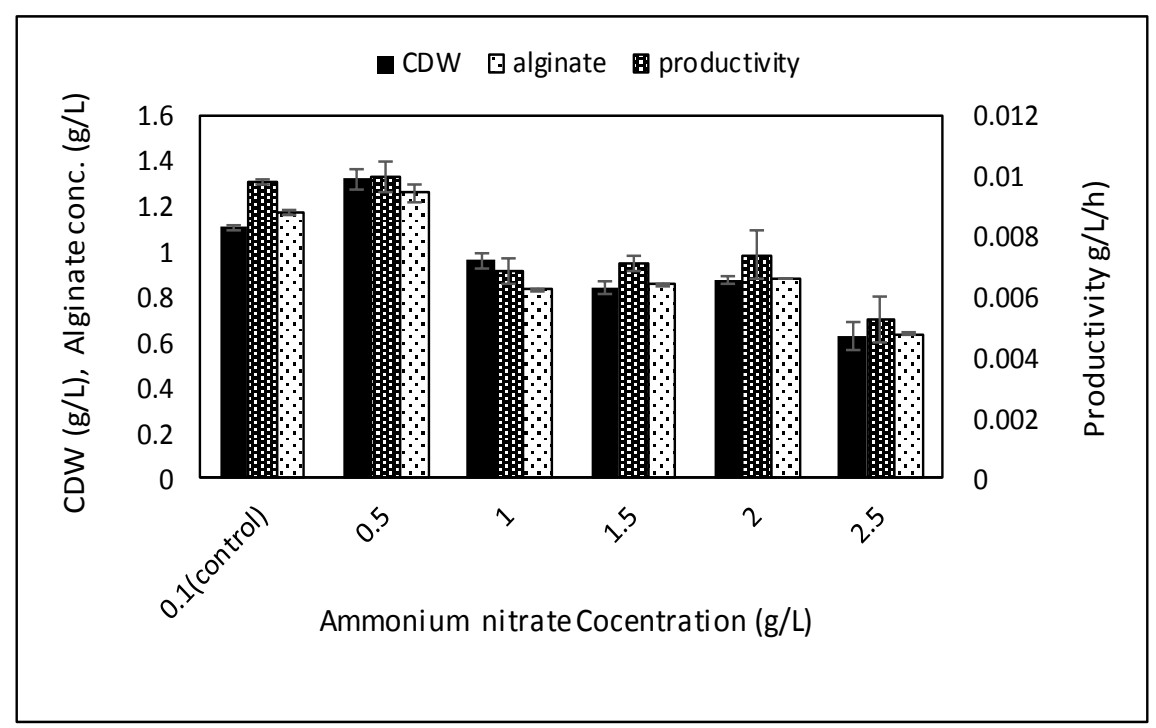

Fig. 2 Effect of different Ammonium nitrate concentrations in sweet whey medium on the production of microbial alginate.

* Legend as Table (1).

The specific $\mathrm{pH}$ affected on the molecular weight of the polysaccharide produced (Jeanes, 1977), and affected directly on synthesis of those enzymes responsible for polysaccharide production and biochemical activities of the cell this was within the optimum $\mathrm{pH}$ range $(6.0$ - 7.5$)$ for synthesis of polysaccharides (Lawson and Sutherland, 1978). In this experiment, all nutritional and environmental conditions were adjusted to the best findings in previous experiment, except that the only variable factor was the $\mathrm{pH}$.

Results of alginate production as influenced by initial $\mathrm{pH}$ values were illustrated in Fig. (3). Increasing or decreasing the initial $\mathrm{pH}$ value of sweet whey medium than 7.0 led to significant decrease in values of cell dry weight and alginate concentration produced by Azotobacter chrococcum. These results indicate that control sweet medium at $\mathrm{pH}$ 7.0 was the most favorable medium could be used for produce cell dry weight and alginate concentration, productivity and yield $(2.489 \mathrm{~g} / \mathrm{L}, 2.48 \mathrm{~g} / \mathrm{L}$, $0.021 \mathrm{~g} / \mathrm{L} / \mathrm{h}$ and $5.51 \%$ ) respectively by Azotobacter chrococcum. These results are in agreement with those obtained by Alibutt et al (2011) they noticed that the maximum alginate production by Azotobacter vinelandii was attained at $\mathrm{pH}=7$ in shake flasks fermentation. The initial PH of 7.0 was found to be optimum for both growth and polysaccharide production by commercial polysaccharideproducing bacteria and decreased when $\mathrm{pH}$ dropped to 5.8 , also $\mathrm{pH}$ affects the permeability of the bacterial cell membrane, thus affecting the biochemical activities of the cell required for biopolymer production (Prasertsan et al 2008).

Effect of agitation of sweet whey medium on alginate production by Azotobacter chrococcum after 5 days at $30^{\circ} \mathrm{C}$

As shown in Fig. (4), it could be found that the maximum CDW, alginate conc., alginate productivity and yield $(2.580 \mathrm{~g} / \mathrm{L}, 2.774 \mathrm{~g} / \mathrm{L}, 0.03 \mathrm{~g} / \mathrm{L} / \mathrm{h}$ and $6.2 \%)$ respectively were at $200 \mathrm{rpm}$ after 5 days of incubation period on whey production medium fermented by Azotobacter chrococcum. Alginate concentration in fermented sweet whey medium by Azotobacter chrococcum was increased by increasing the ratio of agitation. This increase may be due to the intensity of agitation influences on the transport of nutrients into cells, increased agitation may increase microbial productivity, due to better mixing and the elimination of the so-called "dead zone". These results agreement with Moral and Sanin (2011) found that the growth rate of $A$. vinelandii ATCC9046 increased from 0.165 to $0.239 \mathrm{~h}^{-1}$ by the increase of mixing speed from 200 to $400 \mathrm{rpm}$. Whereas, alginate production was found to be the most efficient at $400 \mathrm{rpm}$ with the highest value of $4.51 \mathrm{~g} / \mathrm{l}$ achieved at the end of fermentation. The viscosity of culture broth showed similar trends to alginate production. 


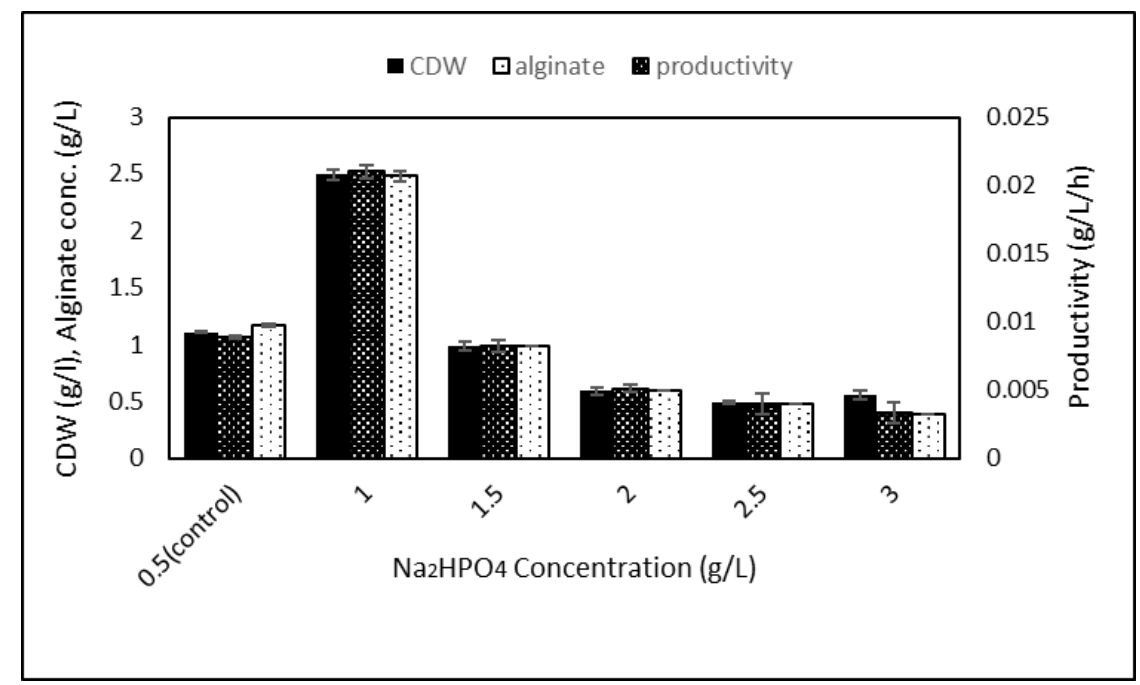

Fig. 3. Effect of different disodium hydrogen phosphate concentrations on alginate production by Azotobacter chrococcum

* Legend as Table (1).

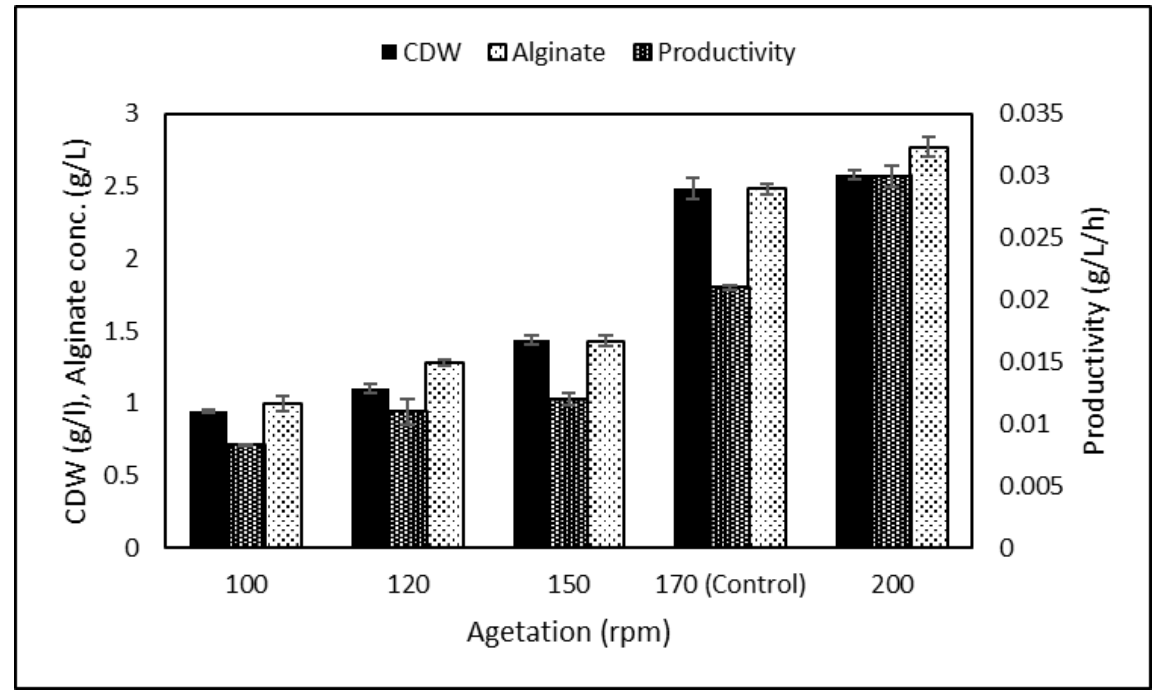

Fig. 4. Effect of agitation of sweet whey medium on alginate production by Azotobacter chrococcum after 5 days at $30^{\circ} \mathrm{C}$.

Effect of inoculums size in sweet whey medium on alginate production by Azotobacter chrococcum after 5 days $30^{\circ} \mathrm{C}$

Data in Table (3) shows that inoculation with 9 $\%$ of standard inoculums Azotobacter chrococcum in modified sweet whey medium at $30^{\circ} \mathrm{C}$ for 5 days on rotary shaker $(200 \mathrm{rpm})$ gave the highest amount of alginate, cell dry weight and productivity of alginate being (3.522 $\mathrm{g} / \mathrm{L}, 3.470 \mathrm{~g} / \mathrm{L} \& 0.029$ $\mathrm{g} / \mathrm{L} / \mathrm{h}$ ) respectively. The inoculums size used by
Alibutt et al (2011) was $2 \%$ of $A$. vinelandii NRRL14641 for maximum alginate production $\left(6.17 \mathrm{gL}^{-1}\right)$ in optimized medium after $110 \mathrm{~h}$ at $30^{\circ} \mathrm{C}$.

The size and the physiological conditions of the inoculum have a profound effect on alginate synthesis by Pseudomonas and Azotobacter. For alginate production in a shaking flask $1-2$ vol- \% inoculum is transfer to a shake flask $(500 \mathrm{ml}$, baffled) with $100 \mathrm{ml} \mathrm{PIA-medium} \mathrm{or} \mathrm{PIA-medium} \mathrm{with} \mathrm{re-}$ duced salt. 
Table 3. Effect of inoculum size on alginate production by Azotobacter chrococcum after 5 days $30^{\circ} \mathrm{C}$.

\begin{tabular}{|c|c|c|c|c|c|}
\hline $\begin{array}{c}\text { Inoculums size } \\
(\%)\end{array}$ & $\begin{array}{c}\text { CDW } \\
\text { (g/L) }\end{array}$ & Alginate con. (g/L) & $\begin{array}{c}\text { Productivity } \\
\text { (g/L/h) }\end{array}$ & $\begin{array}{c}\text { Yield } \\
\text { (\%) }\end{array}$ & $\begin{array}{c}\text { Final } \\
\text { pH }\end{array}$ \\
\hline $\mathbf{1}$ & $0.927 \pm 0.004$ & $0.839 \pm 0.006$ & $0.0069 \pm 0.0006$ & $1.68 \pm 0.09$ & 7.5 \\
$\mathbf{2}$ & $0.935 \pm 0.004$ & $0.946 \pm 0.005$ & $0.0079 \pm 0.0008$ & $2.10 \pm 0.32$ & 7.2 \\
$\mathbf{3}$ & $0.988 \pm 0.005$ & $0.985 \pm 0.008$ & $0.0082 \pm 0.0006$ & $2.18 \pm 0.40$ & 6.9 \\
$\mathbf{4}$ & $1.039 \pm 0.070$ & $1.173 \pm 0.030$ & $0.0098 \pm 0.0029$ & $2.60 \pm 0.30$ & 6.5 \\
$\mathbf{5}$ (Control) & $2.486 \pm 0.021$ & $2.481 \pm 0.053$ & $0.021 \pm 0.0053$ & $4.96 \pm 0.50$ & 6 \\
$\mathbf{6}$ & $2.645 \pm 0.022$ & $2.530 \pm 0.035$ & $0.021 \pm 0.0071$ & $5.06 \pm 0.10$ & 6.2 \\
$\mathbf{7}$ & $2.781 \pm 0.350$ & $2.690 \pm 0.061$ & $0.023 \pm 0.009$ & $5.38 \pm 0.20$ & 6.7 \\
$\mathbf{8}$ & $2.843 \pm 0.009$ & $2.721 \pm 0.044$ & $0.022 \pm 0.008$ & $5.44 \pm 0.60$ & 6.72 \\
$\mathbf{9}$ & $3.522 \pm 0.090$ & $3.470 \pm 0.068$ & $0.029 \pm 0.006$ & $6.94 \pm 0.60$ & 6.76 \\
$\mathbf{1 0}$ & $2.985 \pm 0.053$ & $2.991 \pm 0.035$ & $0.025 \pm 0.0 .012$ & $5.98 \pm 0.50$ & 6.74 \\
\hline
\end{tabular}

But for alginate production in fermentor 2-3 vol$\%$ inoculum from shake flask is transferred to a 3 liter fermentor (Applicon), with 1.4 liter PM5medium. The fermentations are performed at $25^{\circ} \mathrm{C}$ and $\mathrm{pH}$ from start is adjusted to 7.0-7.2 $\mathrm{pH}$. High concentrations of alginate, approximately $20 \mathrm{~g} / \mathrm{L}$ was obtained (Gimmestad et al 2009).

Effect of fermentation time of sweet whey media on Alginate production by Azotobacter chrococcum on whey production medium.

The production of microbial exopolysaccharides has been identified as a potential growth area for the fermentation industry (Sutherland, 2001). Data illustrated by Fig. (5) shows that Azotobacter chrococcum $\mathrm{MH} 249629$ grow exponentially during the first 6 hrs of incubation, thereafter the growth rate decreased gradually (phase of decelerating growth during 6-18 hrs) to more constant (stationary phase) during the period of 18 to $72 \mathrm{hrs}$, then slightly increase during 72 to 120 hrs of incubation.Data illustrated by Fig. (6) shows that cell dry weight was obtained after $72 \mathrm{hrs}$ being $5.654 \mathrm{gL}^{-1}$ with growth parameters of $9.3 \mathrm{~h}^{-1}, 13.4 \mathrm{~h} \& 2.7$ for specific growth rate $(\mu)$, doubling time $\left(t_{d}\right)$ and number of generations $(\mathrm{N})$, calculated during exponential phase respectively. Gradual increase in alginate production was observed during the first $18 \mathrm{hrs}$ fermentation, and then slight increase was attained during stationary phase of growth to record the highest alginate concentration being 5.654 $\mathrm{g} / \mathrm{L}$ after $72 \mathrm{hrs}$. Thereafter, alginate production decrease with increasing the fermentation time for $120 \mathrm{hrs}$. After $72 \mathrm{hrs}$ fermentation period, the alginate yield and productivity were $12.56 \%$ and 0.08 g/L/h, respectively.

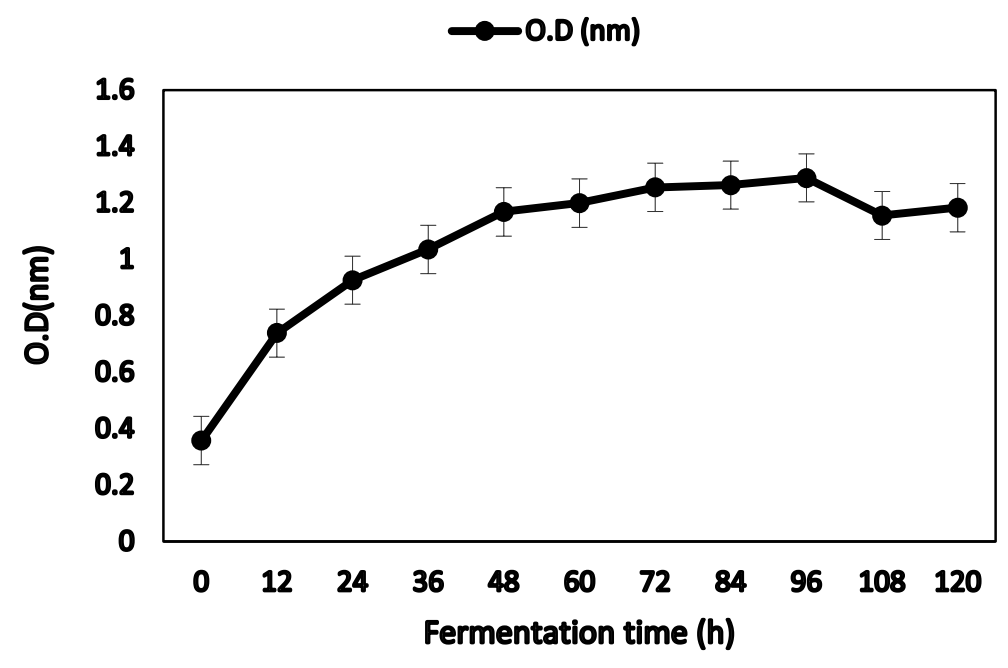

Fig. 5. Effect of growth densities on Alginate production by Azotobacter chrococcum on modified whey sweet production medium. 


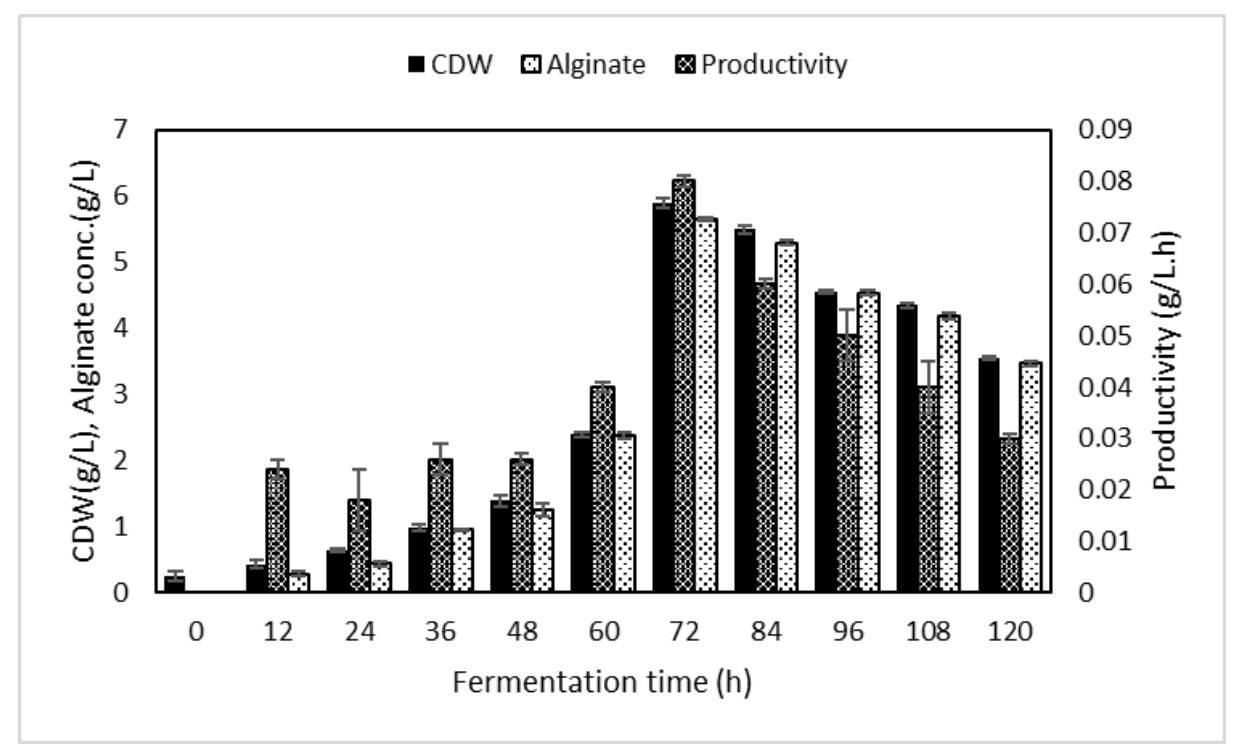

Fig. 6. Effect of fermentation time on Alginate production by Azotobacter chrococcum on modified sweet whey production medium.

In similar studies, Clementi et al (1995) noticed that the stationary values of Azotobacter cell and alginate concentrations were reached after 24 and 36 hrs, respectively. Also, Peña et al (2011) stated that $\mathrm{pH} 7$ was the optimum value for alginate production. Also, it could be noticed that the final $\mathrm{pH}$ value was increased from 7.0 to 9.74 during the fermentation period.

\section{REFRENCECS}

Agrawal, P.K., Agrawal, S. and Shrivastava, R., 2015. Modern molecular lar approaches for analyzing microbial diversity from mushroom compost ecosystem. 3 Biotech. 5, 853-866.

Aleem, A., Isar, J. and Malik, A., 2003. Impact of long-term application of industrial wastewater on the emergence of resistance traits in Azotobacter chroococcum isolated from rhizospheric soil. Bioresour. Technol. 86, 7-13.

Alibutt Z., Ikram-ul-haq and Abdulqader, M., 2011. Alginate production by a mutant strain of Azotobacter vinelandii using shake flasks fermentation. Pak. J. Bot., 43 (2), 1053-1067.

Andersen, T., Strand, B.L., Formo, K., Alsberg, E., and Christensen, B.E. , 2012. Alginates as biomaterials in tissue engineering. In "Carbohydrate Chemistry". Chemical and Biological Approaches. Vol. 37. Rauter, A.P. (ed.). pp. 227-258. Cambridge, UK: The Royal Society of Chemistry.
Anyance Prompaphagorn, 2008. Algnate production by Azotobacter spp. And its Application in enzyme immobilization. Thesis Submitted in Partial Fulfillment of the Requirements for the Degree of Master Science in Biotechnology Suranaree University of Technology Academic.

Belder, A.N., 2010. Dextran, Polysaccharides and their derivatives, $3^{\text {rd }}$ Ed. pp. 417-499, Academic Press, London, U.K.

Brown, M.E., Burlingham, S.K. and Jackson, R.M., 1962. Studies on Azotobacter species in soil I. Comparison of media and techniques for counting Azotobacter in soil. Plant Soil 17, 309-319.

Butt, Z.A., Ikram-ul-haq and Qadeer, M.A. 2011. Alginate production by a mutant strain of Azotobacter vinelandii using shake flask fermentation. Pakistan J. Bot. 43(2), 1053-1067.

Donati, I., and Paoletti, S., 2009 Material properties of alginates. In Alginates: Biology and Applications. Rehm, B.H.A. (ed.), pp. 1-53. Berlin, Heidelberg, Germany: Springer Berlin Heidelberg,

Draget, K., Smidsrød, O. and Skjåk-Bræk, G., 2005. Alginates from algae. Biopolymers Online. doi: 10.1002/ 3527600035.bpol6008.

Emtiazi, G., Ethemdifara Z. and Habibib M.H., 2004. Production of extra-cellular polymer in Azotobacter and biosoeption of metal by exo- 
polymer. African Journal of Biotechnology. 3, 330-333.

Fu. J.F. and Tseng, Y.H., 1990. Construction of lactose utilizing Xanthamonas campestris and production of xanthan gum from whey. Appl. Environ. Microbiol., 56, 919-923.

Gauri, S.S., Mandal, K.C., Dey, S. and Pati, B. R., 2009. Enhanced production and partial characterization of an extracellular polysaccharide from newly isolated Azotobacter sp. SSB81. Bioresource Technology. 100, 42404243.

Gayathri Pandurangan., Jyothi S., Karunakaran T., and David K.J., 2012. Small Scale Production and Characterization of Alginate from Azotobacter chrococcum using different substrates under various stress conditions. International Journal of Applied Biology and Pharmaceutical Technology. 3 (1), 40-45.

George, M.G., Winters M. and Searles D.B. 2001. Bergye's Manual Systematic Bacteriology $2^{\text {nd }}$ Ed., 320 p. Taxonomic out lines of the Prokaryotic Genera, New York, USA,

Hacking, A.J., Taylor I.W.F., Jarman, T.R. and Govan, J.R.W., 2006. Alginate biosynthesis Pseudomonas mendocina. J. Bacteriol., 188(15), 5551-5560.

Horton, B.S., 1993. Whey processing and utilization. Bull. Int. Dairy Fed., 279, 46-49.

Konicek, J., Lasik, J. and Safar, H., 1993. Production of exopolysaccharide by a new mutant strain of Achromobacter delicatulus using whey fermentation. Folia Microbio., 38, 68-70.

Lee, K.Y. and Mooney, D.J. 2012. Alginate: properties and biomedical applications. Prog polym Sci., 37, 106-126.

Looijesteijn, P.J., Trapet, L., de Vries, Abee E., , T. and Hugenholtz, J., 2001. Physiological function of exopolysaccharides produced by Lactococcus lactis. Int. J. Food Microbiol., 64, 71-80.

Painter, P.R. and Marr, A.G., 1963. Mathematics of microbial populations. Annual Rev. Microbiol., 22, 219 - 221.

Pena, C., Galindo, E. and Buchs, J., 2011. The viscosifing power, degree of acetylation and molecular mass of the alginate produced by Azotobacter vinelandii in shake flasks are determined by the oxygen transferate. Process Biochem. 46, 290-297.

Prasertsan, P., Wichienchot S.., Doelle H., and Kennedy J. F., 2008. Optimization for biopolymer production by Enterobacter cloacae WD7.
Journal of Carbohydrate Polymer., 71, 468475.

Ricciardi, A. and Clementi, F., 2002. Exopolysaccharides from lactic acid bacteria: Structure, production and technological applications. Italian Journal of Food Science, 1, 23-45.

Sabra, A., Zeng, P., Lonsdorf, H. and Deckwer, W.D., 2000. Effect of oxygen on formation and structure of Axotobacter vinelandii alginate and its role in protecting nitregenase. Appl. Environ. Microbiol. 66, 4037-4044.

Schwartz, R.D. and Bodie, E.A., 1985. Production of high viscousity whey broths by lactose utilizing Xanthomonas campestris strain. Appl. Environ. Microbial., 50, 1483-1485.

Soto-Urzúa, L. and Baca, B.E., 2001. Mechanisms for protecting nitrogenase from inactivation by oxygen. Rev. Latinoam Microbiol. 43, 37-49.

Stanier, R. Y.; M. Doudoroff and E. A. Adelberg (1970). General Microbiology (3 ${ }^{\text {rd }}$ Ed.), pp. 302-306. Macmillan \& Co. Ltd. London.

Steel, R.G. D., Torrie J.H. and Dickey D.A., 1997. Principles and Procedure of Statistics. A Biometrical Approach $3^{\text {rd }}$ Ed. McGraw Hill Book Co. Inc., New York. pp. 352-358.

Thomas, S., 2000. Alginate dressings in surgery and wound management-Part 1 . J. Wound Care 9, 56-60.

Vargas-García, M.C., López, M.J., Elorrieta, M.A., Suárez, F. and Moreno, J., 2002. Physiology of exopolysaccharide production by Azotobacter vinelandii from 4- hydroxybenzoic acid. J. Ind. Microbiol \& Biotechnol. 29, 129133.

Vela, G.R., Rosenthal, S., 1972. Effect of peptone on Azotobacter morphology. J. Bacterial. 111, 260-266.

Williams, S.T. and Davies F.L., 1965. Use of antibiotics for selective isolation and enumeration of actinomycetes in soil. J. Gen. Microbial., 38, 251-262.

Zadow, J.G., 1987. Whey production and utilization in Oceania. Bull. Int. Dairy Fed., 212, 1216.

Zadow, J.G., 1986. Utilisation of milk components: Whey. In: Robinson, R.K. (Ed), Modern dairy technology, Advances in milk processing. Appl. Sci., 1, 273-317.

Zadow, J.G., 1992. Review and report on whey utilization. A report for the dairy research and development. Bull. Int. Dairy Fed., 314, 21-23. 


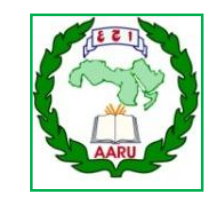

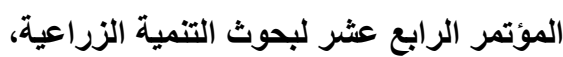

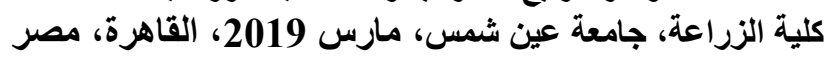

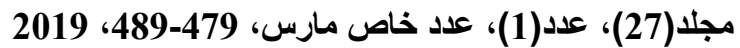

Website: http://strategy-plan.asu.edu.eg/AUJASCl/

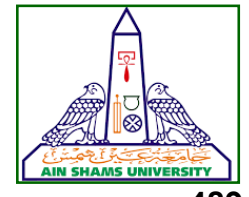

ضبط الظروف المثلى لإنتاجية الألجينات في بيئة الثرش المنتجة بواسطة ميكروب

\section{Azotobacter chrococcum}

[44]

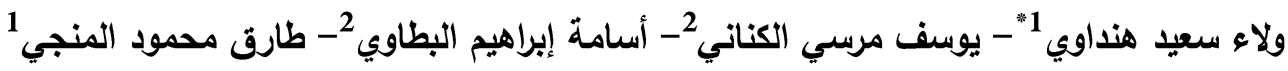

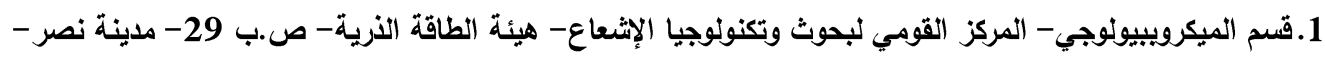

القاهرة- مصر

2.قسم علوم الأغذية- كلية الزراعة- جامعة عين شمس- ص.ب 68- حدائق شبرا 11241 - القاهرة- مصر

"Corresponding author: walaahendawy78@gmail.com

Received 25 October, 2018, $\quad$ Accepted 11 November, 2018

ومعدلات تلقيح مختلفة (1، 2، 3، 4، 5، 6، 7، 8،

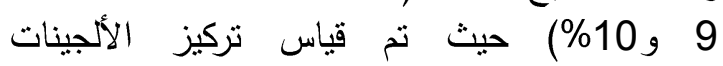

والمحصول الناتج فى نهاية فترة التخمر وكانت النتائج

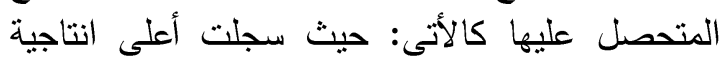

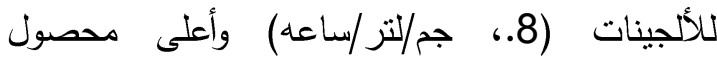

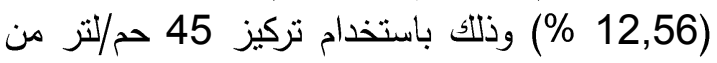

اللاكتوز كمصدر للككربون واضافة (1,5 جم/لتزر) من

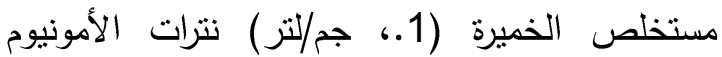

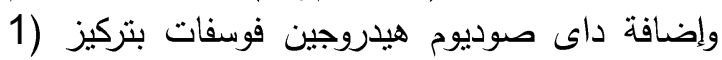

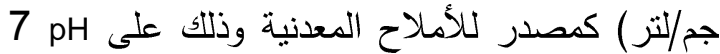

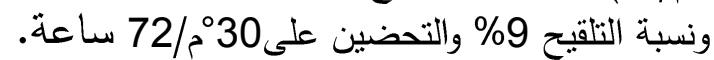

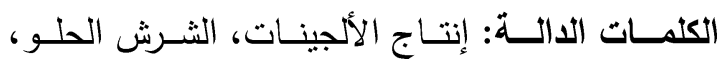

أزوتوباكتر كروكوكوم، ظروف التخمر الأنان

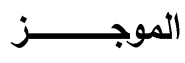

تم استخدام الثرش الحلو لأنتاج الألجينات Azotobacter chrococcum الميكروبية بواسطة ميكروب الأن

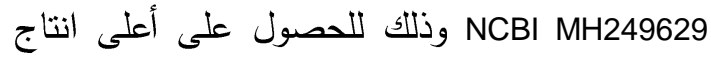
بعد ضبط ظروف الأنتاج وذللك باستخدام بيئة الثرش الثر التاج المحتوية على تركيزات مختلفة من اللاكتوز (25، 20،

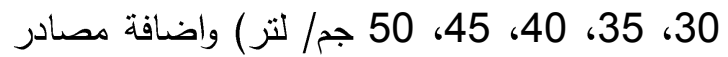
نيتروجينيه عضويه وغير عضويه (مستخلص الخميرة،

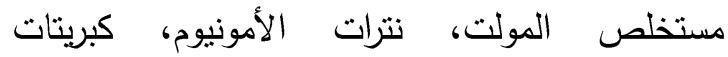
الأمونيوم)، وذلك على درجات حرارة مختلفة

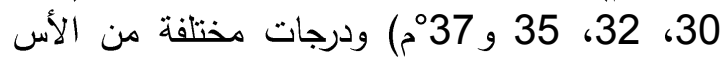

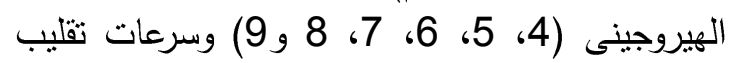

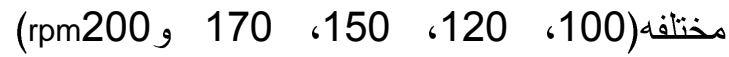

